\title{
Biological parameters of cattle ticks fed on rabbits
}

\author{
Parâmetros biológicos de carrapatos bovinos alimentados em coelhos \\ Maria Alice Zacarias do Amaral ${ }^{1,3 *}$; Márcia Cristina de Azevedo Prata ${ }^{2}$; Erik Daemon ${ }^{3}$ John Furlong ${ }^{2}$ \\ ${ }^{1}$ Animal Experimentation Center, Oswaldo Cruz Institute - Fiocruz \\ ${ }^{2}$ Embrapa Dairy Cattle - EMBRAPA \\ ${ }^{3}$ Federal University of Juiz de Fora - UFJF
}

Received March 21, 2011

Accepted February14, 2012

\begin{abstract}
With the objective of encouraging the use of rabbits as alternative hosts for the cattle tick, four rabbits were infested on the ears and back. From the second day of infestation the developmental stages were observed. The duration of larval engorgement and changes were estimated between six and eight days in the region of the back and between five and seven days in the pinna. The nymphal engorgement and changes occurred at approximately $10.80 \pm 2.65$ days in the dorsal and $11.00 \pm 2.52$ days in the ear, with the engorgement of adults and copulation occurring at $7.03 \pm 2.45$ days, on the dorsal region and $8.55 \pm 1.82$ days in the region of the pinna. The parasitic period ranged from 21 to 29 days (back) and from 23 to 30 days (pinna). The engorged females of the back and ear weighed on average $34.43 \pm 18.73$ and $36.30 \pm 18.10 \mathrm{mg}$, respectively. The nutritional and reproductive efficiency indexes were $17.38 \pm 14.27$ and $26.85 \pm 17.13 \%$ (back) and $17.42 \pm 12.22 \%$ and $30.70 \pm 19.80 \%$ (pinna). Although not appropriate to maintain successive generations of Rhipicephalus (Boophilus) microplus, rabbits can be used for different stages of engorgement of the ixodid, allowing experimental studies.
\end{abstract}

Keywords: Rhipicephalus (Boophilus) microplus, alternate host, biological parameters.

\section{Resumo}

Com objetivo de viabilizar o uso de coelhos como hospedeiros alternativos do carrapato bovino, foram infestados quatro coelhos nas orelhas e no dorso. A partir do segundo dia da infestação, foram observados os estágios de desenvolvimento dos carrapatos. A duração do ingurgitamento e muda larval foi estimada entre seis e oito dias na regiâo do dorso e entre cinco e sete dias no pavilhăo auricular. O ingurgitamento e muda ninfal ocorreram em aproximadamente, 10,80 $\pm 2,65$ dias na regiáo dorsal e 11,00 $\pm 2,52$ dias no pavilháo auricular; e o ingurgitamento e cópula dos adultos ocorreu em $7,03 \pm 2,45$ dias, na regiáo do dorso e em 8,55 $\pm 1,82$ dias na região do pavilhão auricular . O período parasitário variou de 21 a 29 dias (dorso) e de 23 a 30 dias (pavilháo auricular). As fêmeas ingurgitadas do dorso e orelha pesaram, em média, 34,43 $\pm 18,73$ e 36,30 $\pm 18,10 \mathrm{mg}$, respectivamente. Os índices de eficiência reprodutiva e nutricional foram de $17,38 \pm 14,27$ e $26,85 \pm 17,13 \%$ (região do dorso) e de $17,42 \pm 12,22 \%$ e 30,70 $\pm 19,80 \%$ (pavilhão auricular). Embora não sejam adequados para manter sucessivas geraçôes de Rhipicephalus (Boophilus) microplus, os coelhos podem ser empregados para o ingurgitamento dos diferentes estádios deste ixodídeo, viabilizando estudos experimentais.

Palavras-chave: Rhipicephalus (Boophilus) microplus, hospedeiro alternativo, parâmetros biológicos.

\section{Introduction}

Infestation by Rhipicephalus (Boophilus) microplus causes serious economic problems to Brazilian cattle herds. Several authors have reported losses caused by ticks, including lesions of the scalp, decreased productivity, disease transmission, and the cost of acaricide acquisition and application, as well as the need for animal handling facilities. Consequently, there is constant need for investigations relating to controlling this species. Currently, most

\footnotetext{
*Corresponding author: Maria Alice Zacarias do Amaral

Centro de Experimentação Animal, Instituto Oswaldo Cruz - Fiocruz,

Av. Brasil,436, CEP 21040-900, Rio de Janeiro, RJ, Brazil

e-mail: maria.alice@ioc.fiocruz.br
}

studies using experimental infestations in cattle are a relatively expensive activity. In this regard, if it were feasible to use rabbits, this would be advantageous due to the lower requirement for physical space, ease of handling and lower costs, thus differing considerably from cattle (SRIVASTAVA et al., 1986; GUIMARÁES et al., 1996). In continuation with research carried out previously we sought in this present study to observe the parasitic period and fill in gaps in the knowledge about the nonparasitic period from evaluation of the biological performance of $R$. (B.) microplus in body regions of rabbits, in order to facilitate use of rabbits as an alternative host in experimental studies involving this tick species. 


\section{Materials and Methods}

In the parasitic phase, experimental infestations were established using larvae of $R$. (B) microplus in four rabbits (Oryctolagus cuniculus). Each animal was inoculated in the ear and back, which constituted the experimental treatments. In each of these regions, 800 infesting larvae were placed as recommended by Guimarães et al. (1996). Containment devices were attached to the upper back and ears, adapting the technique used by Neitz et al. (1971). After each daily collection of the engorged females that had dropped, they were then weighed on an analytical scale and identified in a Petri dish (Figure 1), while kept in a BOD incubator at a temperature of $27 \pm 1{ }^{\circ} \mathrm{C}$ and relative humidity of greater than $80 \%$. They were then observed to detect the onset of oviposition. Twenty-four hours after the onset, (Figure 2) the eggs were collected, weighed and packed in syringes, and then identified and kept in an incubator to monitor the larva hatching process. Throughout the laying period, at intervals of $24 \pm 1$ hours, the egg masses from each female were weighed and transferred to syringes, which were the experimental unit for the processes relating to the incubation and hatching of the larvae. Three days after the end of laying, the females were weighed in order to ascertain the weight loss that had occurred during the process, so that the nutritional efficiency ratio (NER) could be calculated (BENNETT, 1974). Based on this methodology, we considered each body region to be a treatment area, each tick to be an experimental unit for the parasitic and laying phases, and every syringe containing egg masses from each female to be an experimental unit for the incubation and hatching processes. Using this approach, data on biological parameters were then gathered. The parameters for the period of engorgement and larval changes were the estimated number of days between infestation and the day of obtaining modal nymphs in each body region. The parameters for the period of nymphal engorgement and changes were the weighted average number of modal days taken to obtain nymphs and view every adult in each body region. The parameters for the period of engorgement and mating of adults were the weighted average number of modal days taken to obtain adults and the fall of each female in each body region. The parameters for the percentage recovery of engorged ticks were the percentage of engorged females obtained in relation to half the total number of larvae infesting (number of larvae that would give rise to females, considering the gender ratio of $1: 1$ ), pre-laying period (PPP), spawning period (PP), weight of egg mass/female $(\mathrm{mg})$, weight of females at the beginning and end of laying $(\mathrm{mg})$, weight of females three days after laying, incubation period (IP) in each experimental unit (syringe laying of females), percentage hatchability (\% E), visual estimation of hatched larvae in relation to the total corresponding to the eggs laid by each female, laying rate (every 24 hours), reproductive efficiency index (IER) and nutritional efficiency ratio (NER), as described by Bennett (1974).

Statistical analysis was performed on the data, consisting of Student's $t$ test at 5\% to investigate whether there were any significant differences in the biological parameters of the ticks, as determined by local engorgement. If the sampling was characterized as lacking normal distribution, parametric Student's $t$ tests were

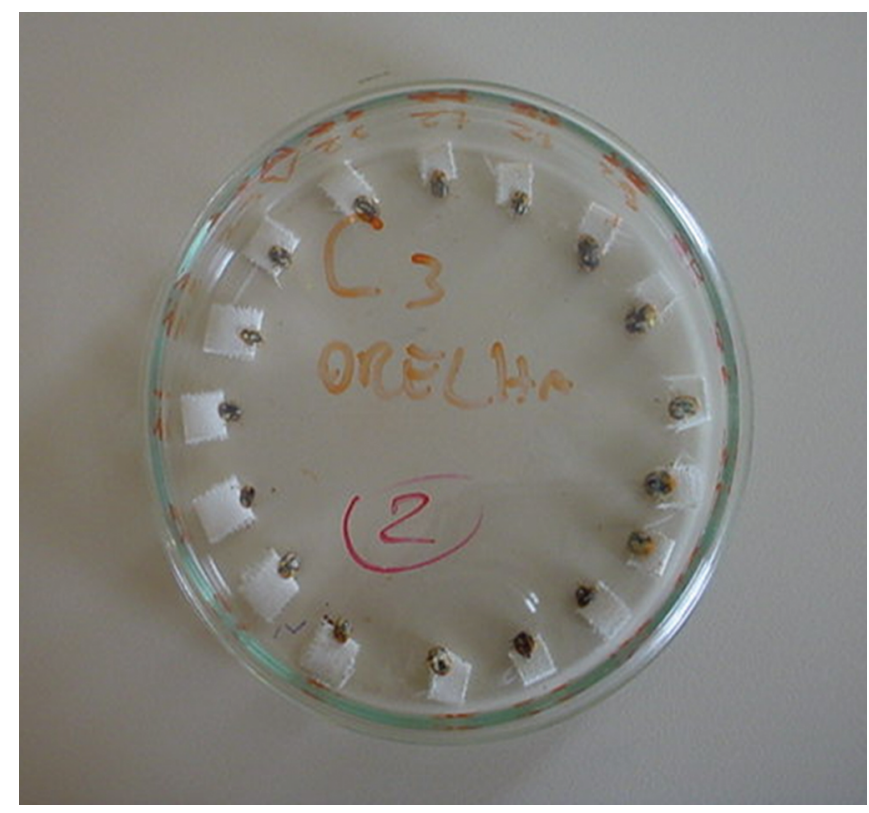

Figure 1. Engorged females of Rhipicephalus (Boophilus) microplus obtained from artificial infestations in rabbits, placed in a petri dish to monitor the nonparasitic phase.

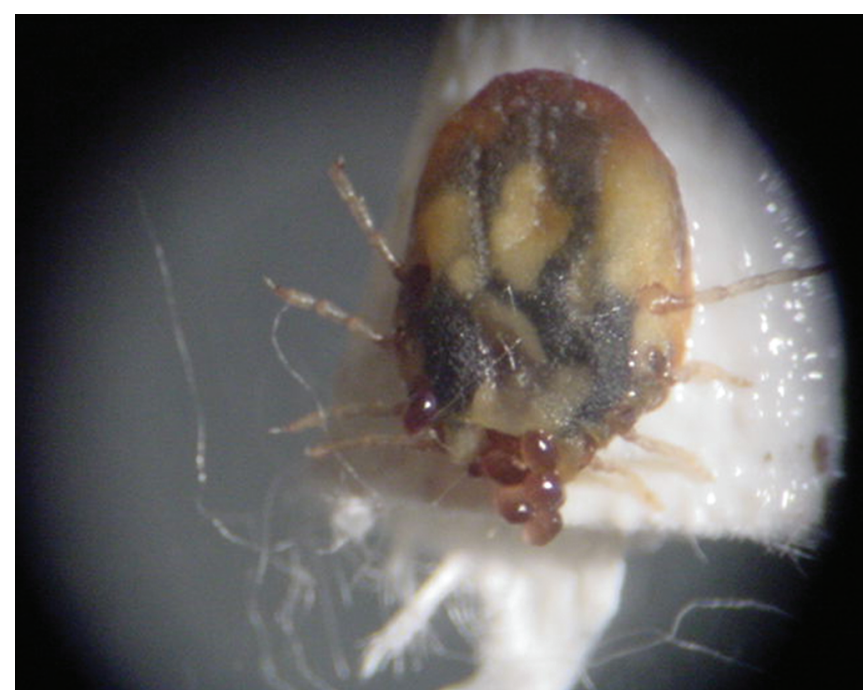

Figure 2. Note the beginning of laying by female Rhipicephalus (Boophilus) microplus, obtained from artificial infestations in rabbits.

replaced by the nonparametric Mann-Whitney test. Values expressed as percentages were transformed into the arcsine root prior to statistical tests.

\section{Results and Discussion}

Two hundred forty nine engorged females of $R$. (B.) microplus were recovered: $10.69 \%$ (171) from the animals' ears and $4.88 \%$ (78) from their backs. This low female recovery rate may be associated with intraspecies competition between ticks for the physical space needed, as previously observed by other authors (GUIMARÃES et al., 1996). Another factor that may have 
influenced the low tick recovery is that the animals can drop out of the back restraining device through mechanical reactions from the hosts (BITTENCOURT et al., 1990; DAEMON et al., 1998). Cunha (1978) observed that adult females had died because the inflammatory reaction had interfered with the blood supply to tissues. Guimarães (1995) found experimentally that the inflammatory reaction was worsened as the number of infesting larvae increased, and suggested that as the quantity of parasites rose, the toxins in the tissue also rose, thereby increasing the degree of allergic reaction interfering with instar development.

The process of observing the changes and engorgement of the larvae during development of $R$. (B.) microplus was hampered by difficulty in viewing them because of their small size and the large number of specimens, and these data were only estimated. However, despite this, it is believed that such information may contribute towards further research involving this parasite. It is noteworthy that some parameters for the nonparasitic and parasitic stages of $R$. (B.) microplus, with rabbits as alternative hosts, were first described in the complementary work by Guimarães et al. (1996).

Table 1 shows the duration of the larval engorgement process. This change was estimated to take between six and eight days on the dorsum and between five and seven days in the ear region. Larger quantities of specimens were obtained at the upper limits of each range, and modal days were considered for such processes in each body region. In the literature, there is no data on the duration of each parasitic stage of $R$. (B.) microplus in rabbits, in order to make comparisons. In this regard, the present study is a pioneer. According to Tate (1941), the larval engorgement and changes in goats took 7 to 18 days, and in sheep, 7 to 12 days, for the larval stage. In experiments on dogs, the same author found that the changes took 8 to 16 days, for the larval stage. In the experiment by Daemon et al. (1998), larval engorgement and changes in goats took 5 to 7 days. The duration of the larval stage in cattle was 5.5 days (HITCHCOCK, 1955a). From analysis on these records, we were able to confirm that the parasitic larval stage became extended in alternative hosts, possibly through adaptation to host species.

The nymphal engorgement and changes occurred in approximately $10.80 \pm 2.65$ days in the dorsal region and $11.00 \pm 2.52$ days in the pinna region. In goats, this process can occur in 7 to 27 days (TATE, 1941; DAEMON et al., 1998). In sheep, the nymphal stage ranged from 7 to 13 days, and in dogs from 8 to 16 days (TATE, 1941). In cattle, the duration of the process was shorter: around 7 to 8 days (HITCHCOCK, 1955a), confirming previous information on the need for greater adaptation for alternate hosts.

In the present study, engorgement and mating of adults occurred in $7.03 \pm 2.45$ days on the dorsum and $8.55 \pm 1.82$ days in the pinna region. In a study on goats, Daemon et al. (1998) obtained an average value of 6.7 days. In cattle, this period was eight days (HITCHCOCK, 1955a). From analysis on these values, it was found that the host species has a considerable and significant influences on the immature stages. There was no evidence for a parasitic phase in the adult Rhipicephalus (Boophilus) microplus.

It was observed that the range for the parasite sampling period in the dorsal region was 21 to 29 days, and it was 23 to 30 days in the ear region. Thus, there was no significant difference between the averages of 25.97 and 26.72 days, respectively, found from the back and ears. These results are also similar to those found in rabbits (24-31 days) by Guimarães et al. (1996). Tate (1941) obtained parasitic periods in goats (20 to 38 days) and sheep (20 to 37 days) with greater range than what was found in the present work. The range in dogs (22 to 29 days) was similar to what was recorded in rabbits. Daemon et al. (1998) found a shorter average duration of the parasitic phase in goats (22.5 days) than in the present study.

The parasitic period for ticks on cattle reported in the literature is 21.9 days (HITCHCOCK, 1955a), i.e. shorter than the average periods of the present study (25.97 and 26.72 days), thus confirming the previously mentioned effect of the host species on the duration of the change process of $R$. (B.) microplus. Out of

Table 1. Duration of different developmental stages of Rhipicephalus (Boophilus) microplus fed on rabbits.

\begin{tabular}{|c|c|c|c|}
\hline \multirow[t]{2}{*}{ Parameter (days) } & \multirow{2}{*}{$\begin{array}{l}\text { Central trend } \\
\text { measurements }\end{array}$} & \multicolumn{2}{|c|}{ Body region } \\
\hline & & Back & Ears \\
\hline $\begin{array}{l}\text { Period of larval engorgement and changes } \\
* *\end{array}$ & - & 8 & 7 \\
\hline $\begin{array}{l}\text { Period of nymphal engorgement and changes } \\
* \text { or** }\end{array}$ & $\begin{array}{l}\text { Value of } \mathrm{n} \\
\mathrm{x} \pm \mathrm{s}\end{array}$ & $10.80 \pm 2.65$ & $11.00 \pm 2.52$ \\
\hline $\begin{array}{l}\text { Period of engorgement and adult mating } \\
* \text { or }^{* *}\end{array}$ & $\begin{array}{c}\text { Value of } \mathrm{n} \\
\mathrm{x} \pm \mathrm{s}\end{array}$ & $7.03 \pm 2.45$ & $8.55 \pm 1.82$ \\
\hline $\begin{array}{l}\text { Parasitic period } \\
*\end{array}$ & $\begin{array}{c}\mathrm{n} \\
\mathrm{x} \pm \mathrm{s} \\
\text { Limits } \\
\end{array}$ & $\begin{array}{c}78 \\
25.97^{\mathrm{a}} \pm 2.39 \\
21.00-29.00\end{array}$ & $\begin{array}{c}171 \\
26.72^{\mathrm{a}} \pm 1.94 \\
23.00-30.00\end{array}$ \\
\hline $\begin{array}{l}\text { Pre-laying period } \\
* *\end{array}$ & $\begin{array}{c}\mathrm{n} \\
\mathrm{x} \pm s \\
\text { Limits }\end{array}$ & $\begin{array}{c}54 \\
3.85^{\mathrm{a}} \pm 1.80 \\
1.00-8.00\end{array}$ & $\begin{array}{c}133 \\
3.39^{\mathrm{a}} \pm 1.14 \\
1.00-6.00\end{array}$ \\
\hline $\begin{array}{l}\text { Laying period } \\
*\end{array}$ & $\begin{array}{c}\mathrm{n} \\
\mathrm{x} \pm s \\
\text { Limits }\end{array}$ & $\begin{array}{c}54 \\
5.55^{\mathrm{a}} \pm 1.88 \\
2.00-11.00\end{array}$ & $\begin{array}{c}133 \\
5.17^{\mathrm{a}} \pm 2.05 \\
1.00-10.0\end{array}$ \\
\hline
\end{tabular}

Measurements with the same letter followed by the same line do not significantly differ at the $5 \%$ level. $\overline{\mathrm{x}}$ - mean; $s$ - standard challenge; *Student's $t$ test;

**Mann-Whitney test. 
the 78 engorged females (Table 2) recovered from the dorsum, 14 died after weighing, between the first and third day after falling off the host, before laying commenced. It is believed that this must have occurred due to early detachment of females because of competition among individuals. The same occurred with the females collected from the ear: out of the 171 females, 38 died over the first days, before laying started.

The mean weights of the engorged females were 34.43 and $36.30 \mathrm{mg}$ for the experimental groups from the back and ear, respectively, i.e. showing no significant differences at the $5 \%$ level. This result allows us to deduce that these two regions offer similar conditions for feeding and parasitism. However, there are anatomical and physiological differences between the two regions, given that the back is a flat region and thus would theoretically tend to facilitate larva attachment and development to the stage of engorged females. Guimarães et al. (1996) found that ear infestation in rabbits, using 800 larvae, produced engorged females with an average weight of $38.88 \mathrm{mg}$, similar to what was obtained in the present work, within the two body regions. The similarity of results between the two experiments is due possibly to the fact that they used the same methodology, in addition to having used the same host species with similar age and race.

It was observed that the weights of the engorged females were lower than those found in the study by Daemon et al. (1998). Although lower, these were similar to what was obtained with females hosted on cattle (DAVEY et al., 1980; BITTENCOURT et al., 1990; GLÓRIA et al., 1993; BORGES et al., 2001). From analysis on these records, it can be argued that use of rabbits as an alternative host for engorgement of females in the laboratory is a viable alternative when there is no requirement regarding the weight of engorged females. This reflects the influence of host species, based on factors such as the immune system (SRIVASTAVA et al., 1987), the host's defense mechanism (licking, scratching and immune response) (CASTRO; PEREIRA, 1946) and resistance due to blood levels and nutrition (OLIVEIRA; ALENCAR, 1990; MANGOLD et al., 1994; VIANNA et al., 1995).

The pre-laying periods were $3.85 \pm 1.80$ and $3.39 \pm 1.14$ days for the back and ear respectively. These periods were similar, thus showing that the time required for the engorged females to begin laying is irrespective of the body region. Furthermore, this parameter seems not to be influenced by the host species in question, given that studies on the nonparasitic phase of $R$. (B.) microplus in cattle and goats produced results similar to those of the present work (HITCHCOCK, 1955b; ALVARADO; GONZALES., 1979; DAVEY et al., 1980; BITTENCOURT et al., 1990; GLÓRIA et al., 1993).

The oviposition periods of the females on the back (5.55 days \pm 1.88$)$ and ears (5.17 days \pm 2.05$)$ were statistically similar to what was found by Guimarães et al. (1996), who also used rabbits (five to seven days). These periods were shorter than those recorded in experiments with goats (DAEMON et al., 1998) and cattle (HITCHCOCK, 1955b). This difference in the number of laying days between females on rabbits and other species can be explained by the weight of the engorged female. Rabbits present low numbers because there is a correlation between the weight of the engorged female and the number of eggs laid. Therefore, smaller females lay fewer eggs, thus taking fewer days for the process, as described by Santos and Furlong (2002).

Table 2. Biological parameters of Rhipicephalus (Boophilus) microplus engorged on rabbits, kept at $27 \pm 1{ }^{\circ} \mathrm{C}$, relative humidity above $80 \%$ and scotophase.

\begin{tabular}{|c|c|c|c|}
\hline \multirow[t]{2}{*}{ Parameter } & \multirow[t]{2}{*}{ Central } & \multicolumn{2}{|c|}{ Body region } \\
\hline & & Back & Ears \\
\hline $\begin{array}{l}\text { Weight of engorged females } \\
(\mathrm{mg})^{*}\end{array}$ & $\begin{array}{c}\mathrm{n} \\
\mathrm{x} \pm \mathrm{s} \\
\text { Limits }\end{array}$ & $\begin{array}{c}78 \\
34.43^{\mathrm{a}} \pm 18.73 \\
10.60-92.00\end{array}$ & $\begin{array}{c}171 \\
36.30^{\mathrm{a}} \pm 18.10 \\
6.00-122.00\end{array}$ \\
\hline $\begin{array}{l}\text { Weight of eggs } \\
(\mathrm{mg})^{*}\end{array}$ & $\begin{array}{c}\mathrm{n} \\
\mathrm{x} \pm \mathrm{s} \\
\text { Limits }\end{array}$ & $\begin{array}{c}54 \\
6.76^{\mathrm{a}} \pm 7.09 \\
0.45-35.30\end{array}$ & $\begin{array}{c}133 \\
6.90^{\mathrm{a}} \pm 5.97 \\
0.51-36.45\end{array}$ \\
\hline $\begin{array}{l}\text { Weight of females at the end of laying } \\
(\mathrm{mg})^{*}\end{array}$ & $\begin{array}{c}\mathrm{n} \\
\mathrm{x} \pm \mathrm{s} \\
\text { Limits }\end{array}$ & $\begin{array}{c}54 \\
16.04^{\mathrm{a}} \pm 10.35 \\
0.70-48.50\end{array}$ & $\begin{array}{c}128 \\
17.72^{\mathrm{a}} \pm 12.06 \\
1.06-91.60\end{array}$ \\
\hline $\begin{array}{l}\text { Reproductive efficiency index } \\
(\%)^{*}\end{array}$ & $\begin{array}{c}\mathrm{n} \\
\mathrm{x} \pm s \\
\text { Limits }\end{array}$ & $\begin{array}{c}54 \\
17.38^{\mathrm{a}} \pm 14.27 \\
1.95-89.37\end{array}$ & $\begin{array}{c}133 \\
17.42^{\mathrm{a}} \pm 12.22 \\
2.30-88.50\end{array}$ \\
\hline $\begin{array}{l}\text { Nutritional efficiency index } \\
(\%)^{* *}\end{array}$ & $\begin{array}{c}\mathrm{n} \\
\mathrm{x} \pm s \\
\text { Limits }\end{array}$ & $\begin{array}{c}54 \\
26.85^{\mathrm{a}} \pm 17.13 \\
1.02-89.90\end{array}$ & $\begin{array}{c}128 \\
30.70^{\mathrm{a}} \pm 19.80 \\
2.56-96.33\end{array}$ \\
\hline $\begin{array}{l}\text { Incubation period } \\
(\text { days })^{*}\end{array}$ & $\begin{array}{c}\mathrm{n} \\
\mathrm{x} \pm s \\
\text { Limits }\end{array}$ & $\begin{array}{c}33 \\
22.70^{\mathrm{a}} \pm 1.74 \\
19.00-26.00\end{array}$ & $\begin{array}{c}61 \\
23.40^{\mathrm{b}} \pm 1.53 \\
19.00-26.00\end{array}$ \\
\hline $\begin{array}{l}\text { Percentage hatching } \\
(\%)^{*}\end{array}$ & $\begin{array}{c}\mathrm{N} \\
\mathrm{x} \pm s \\
\text { Limits }\end{array}$ & $\begin{array}{c}33 \\
35.75^{\mathrm{a}} \pm 25.59 \\
5.00-90.00\end{array}$ & $\begin{array}{c}61 \\
34.34^{\mathrm{a}} \pm 22.40 \\
5.00-95.00\end{array}$ \\
\hline
\end{tabular}

Measurements with the same letter followed by the same line do not significantly differ at the $5 \%$ level. $\bar{x}$ - mean; $s$ - standard challenge; *Student's $t$ test;

** Mann-Whitney test. 
The weight of the eggs, the residual weight of the females and the indices of reproductive efficiency and nutrition in the two groups are presented in Table 2 . There was a range from 0.45 to $35.30 \mathrm{mg}$ of the weight of the egg mass from the back, with an average of $6.76 \mathrm{mg}$, which is statistically similar to the average of $6.90 \mathrm{mg}$ obtained from the pinna region, where the range was from $0.51 \mathrm{mg}$ to $36.45 \mathrm{mg}$. This similarity can be explained by the fact that the weights of the engorged females in the two regions were similar, thus confirming the aforementioned direct relationship between the weight of engorged females and number of eggs laid (SANTOS; FURLONG, 2002). The weight of egg masses reported in the literature concerning the tick $R$. (B.) microplus on cattle and the weight of females were higher than those of the present study (BITTENCOURT et al., 1990; GLÓRIA et al., 1993). This confirms the statement about the close relationship between these two parameters (weight of engorged females and egg weight). According to Borges et al. (2001), measures that increase the weight of engorged females increase the weight of egg masses (SANTOS; FURLONG, 2002).

The average weights of the females at the end of oviposition, from the dorsal and ear, were $16.04 \pm(0.70-48.50)$ and $17.72 \pm(1.06$ to 91.60$) \mathrm{mg}$, respectively. These can be considered statistically similar. These weights were much lower than those found in the literature for $R$. (B.) microplus in goats $(62.1$ and $67.4 \mathrm{mg}$ in the first and second generations respectively) (DAEMON et al., 1998 ) and cattle $(63.60 \mathrm{mg})$ (GLÓRIA et al., 1993) due to the small size of the engorged females from rabbit hosts. The indices of reproductive efficiency and nutrition were also low. The range obtained for the first parameter was 1.95 to $89.37 \%$ for the dorsum and 2.30 to $88.50 \%$ for the ear region, with no statistically significant difference between the means of 17.38 and $17.42 \%$ obtained from the respective regions. The mean values differed significantly from the second parameter: 26.85 and $30.70 \%$ respectively from the dorsal region and ears, and these were found to range from 1.02 to $89.90 \%$ and from 2.56 to $96.33 \%$.

Both regions produced low engorgement, egg production was significantly lower and the average weights of the egg masses were $6.76 \mathrm{mg}$ from the back and $6.90 \mathrm{mg}$ from the ears. These reflect low rates of reproductive efficiency, thus demonstrating, in the case of this population, low reproductive capacity after engorgement. A similar situation occurred in relation to the nutritional efficiency index. However, the average weight loss of females at the end of laying did not reach the $74.32 \%$ recorded by Alvarado and Gonzales (1979) in their experiment. The blood processing capacity in eggs was low in this study, and it can therefore be assumed that there was considerable deviation of body mass for other metabolic processes, thereby characterizing a situation of discomfort and/or stress for the ticks. Although both these parameters were considered low (IER and NER of 17.38 and $26.85 \%$ ), compared with findings in the literature on rabbits (IER $29.10 \%$ and NER $50.32 \%$ ) (GUIMARÁES et al., 1996), these results can be correlated with a possible difference between populations of the same species. Morphological differences relating to tick provenance have been observed (FAMADAS; FACCINI, 1989). These differences may be caused by several factors, such as selection pressure due to acaricides (FURLONG et al., 2004) and geographical isolation, among other causes. These factors modify the profile of a population and consequently, the biological parameters. In relation to the other alternative host (goats), both indices in the present study were found to be low. This parameter may have been influenced by the fact that because goats are physiologically similar to the preferred host species for ticks (cows), they provide conditions that are more suitable than those of rabbits. The indices of nutritional and reproductive efficiency obtained in this study were also lower than those recorded from cattle-hosted ticks by Alvarado and Gonzales (1979) and Glória et al. (1993). Again, these results may have been caused by different factors, but the main factor is the use of hosts that can be considered to be more suitable than rabbits for development of the tick $R$. (B.) microplus.

Among the secondary causes, it should be mentioned that the host reaction is individual, regardless of the species concerned (CASTRO; PEREIRA, 1946). It was found in rabbits infested with $R$. (B.) microplus that the inflammatory reactions caused by tick bites meant that the larvae could not have access to any source of blood. They therefore fed on substances resulting from the lysis that occurs in the area of acute cellular infiltration. This would lead to engorgement of larvae with a pallid hue, while retaining the ability to make changes and thereby leading to production of light females with low reproductive performance (CUNHA, 1978; GUIMARÃES, 1995).

Regarding the oviposition rate of the females fed on the two body regions, the average daily peak egg production was reached between the second and third days after the onset of laying. In this range, the total masses of eggs laid ranged from 14.80 to $14.50 \%$ for females on the back, and from 16.70 to $16.12 \%$ for females on the pinna. The peaks were not so pronounced, with higher concentration of the metabolism between the second and sixth days, regarding the position of females on the dorsal region and between the second and fourth days on the ear.

The periods required for $50 \%$ of the egg mass to be laid were three and four days, respectively, in the ear and back regions. It was observed that about $90 \%$ of the total average oviposition had been laid by the eighth day in the ear region, and by the ninth day on the dorsum, thus suggesting that the metabolism in the laying process was faster among females on the pinna. It also appears that the curve of the number of eggs laid daily showed similarities with those observed in experiments using different host species conducted by Hitchcock (1955b), Davey et al. (1980) and Glória et al. (1993), with maximum numbers in the early days of laying.

Table 2 presents a range from 19 to 26 days for the incubation period for eggs laid by females in the two regions, thus resulting in a significant difference between the averages, of 22.70 and 23.40 days for the back and ears respectively. The difference between the averages for the two regions reflects the need for a longer incubation period for the eggs from the engorged females on the ear to complete the process, and then for the larvae to start to hatch. This faster metabolism of incubation on the back suggests the possibility that an offset may exist due to the slower metabolism developed during the laying in this region. From analysis on the results presented in relation to the incubation period, there were also changes in the non-parasitic phase, possibly promoted by local engorgement of the ticks (parasitic phase). The reverse process, i.e. changes in the parasitic phase determined by the maintenance conditions during the nonparasitic phase, was noted by Bellato and Daemon (1997) (Rhipicephalus sanguineus) 
(Latreille, 1806) and Chacón et al. (2002) (A. cajennense). The averages obtained for the incubation period were lower than those recorded with cattle-hosted ticks (23 to 25 days) (DAVEY et al., 1980; BITTENCOURT et al., 1990; GLÓRIA et al., 1993). This difference may be explained by the host species, and a series of factors such as the body region where the host was parasitized and/or the methodology used in each experiment.

No significant difference in the percentage of hatching was observed between the regions. The range obtained was from 5 to $90 \%$ (back) and 5 to $95 \%$ (pinna), with averages of 35.75 and $34.34 \%$ for the back and the pinna. These values were lower than those found by Guimarães et al. (1996), who found a rate of $96.65 \%$. These low values may be a consequence of the aforementioned factors that are responsible for differences in population profiles, which change the biological parameters.

\section{Conclusions}

From analysis on the results, we can conclude that the host species has a clear influence on the parasitic period of the larvae and nymphs of $R$. (B.) microplus. The use of rabbits in experimental studies to engorge $R$. (B.) microplus is feasible, but with reservations, depending on the type of study that will be performed, for example, when there is no requirement regarding the weight of the engorged females.

\section{References}

Alvarado RU, Gonzales JC. A postura e a viabilidade do Boophilus microplus (Canestrini, 1887) (Acarina, Ixodidae) em condições de laboratório. Rev Latinoam Microbiol 1979; 21: 31-36. PMid:293838.

Bellato V, Daemon E. Influência da temperatura de manutenção da fase não parasitária sobre a fase parasitária de Rhipicephalus sanguineus (LATREILLE, 1806) (ACARI: IXODIDAE). Rev Bras Parasitol Vet 1997; 6 (1): 15-19.

Bennett GF. Oviposition of Boophilus micropus (Canestrini) (Acarida: Ixodidae) I. Influence of tick size on egg production. Acarologia 1974; 16(1): 52-61. PMid:4463680.

Bittencourt AJ, Fonseca AH, Faccini JLH, Bueno BF. Comportamento do Boophilus microplus (Canestrini, 1887) (Acari) em infestaçôes artificiais e naturais em diferentes hospedeiros. Arq Univ Fed Rural Rio J 1990; 173-183.

Borges LMF, Carneiro JR, Gomes AG, Moreira PC. Influência do peso inicial e da estaçáo do ano na conversáo em ovos de fêmeas de Boophilus microplus (Acarida:Ixodidae). Cienc Anim Bras 2011; 2(2): 127-131.

Castro MP, Pereira C. Alimentação das proteroninfas de "Boophilus (Uroboophilus) microplus Can., 1888” (IXODIDAE) com os restos necróticos da reaçâo tissular do hospedeiro. Arq Inst Biol São Paulo 1946; 17: 149-161.

Cunha DW. Estudos da toxidade de alguns carrapatos comumente encontrados no Brasil (Acarina: Ixodidae) [Dissertação]. Rio de Janeiro: Universidade Federal Rural do Rio de Janeiro; 1978.

Daemon E, Prata MCA, Faccini JLH. Goats as alternative hosts of Boophilus microplus (Acari: Ixodidae). Rev Bras Parasitol Vet 1998; 7(2): 123-128.
Davey RB, Garza JG, Thompson GD, Drummond RO. Ovipositional biology of the southern cattle tick, Boophilus microplus (Acari: Ixodidae) in the laboratory. J Med Entomol 1980; 17 (2): 117-121.

Famadas KM, Faccini JLH. Variação morfológica de Boophilus microplus (Canestrini, 1887) (Acari: Ixodidae), no Brasil. Arq Univ Fed Rural Rio J 1989; 73-81.

Furlong J, Martins JRS, Prata MCA. Controle estratégico do carrapato dos bovinos. A Hora Vet 2004; 137: 53-56.

Glória MA, Faccini JLH, Daemon E, Grisi L. Biologia comparativa da fase não parasitária de estirpes de Boophilus microplus (CAN. 1887) resistente e sensível a carrapaticidas em condições de laboratório. Rev Bras Parasitol Vet 1993; 2(2): 79-84.

Guimarães da Silva CL. Relação entre o número de larvas e Fêmeas ingurgitadas em infestaçōes experimentais de coelhos com Boophilus microplus (Canestrini, 1887) (Acari: ixodidae) [Dissertação]. Rio de Janeiro: Universidade Federal Rural do Rio de Janeiro; 1995.

Guimarães da Silva CL, Cunha DW, Daemon E, Faccini JLH. Efeito o número de larvas de Boophilus microplus (Can., 1887) (Acari: Ixodidae) sobre a recuperaçáo de fêmeas ingurgitadas em coelhos 1996. Rev Bras Cienc Vet 3(2): 59-61.

Hitchcock LF. Studies of the non-parasitic stages of the castle tick, Boophilus microplus (Canestrini, 1887) (Acarina: Ixodidae). Aust J Zool 1955a; 3(3): 295-311. http://dx.doi.org/10.1071/ZO9550295

Hitchcock LF. Studies of the parasitic stages of the cattle tick, Boophilus microplus (Canestrini, 1887) (Acari: Ixodidae). Aust J Zool 1955b; 3(2): 145-155. http://dx.doi.org/10.1071/ZO9550145

Mangold AJ, Aguirre DH, Gaido AB, Guglielmone AA. Seasonal variation of tick (Ixodidae) in Bos taurus X Bos indicus cattle under Rotational grazing in forested and deforested habitats in northwestern Argentina. Vet Parasitol1994; 54(4): 389-395. http://dx.doi.org/10.1016/03044017(94)90005-1

Neitz WO, Boughton F, Walters HS. Laboratory investigations on the life cycle of the Karoo paralysis tick (Ixodes rubicudus Neumann, 1904). Onderst. J Vet Res 1971; 38(3): 215-224

Oliveira GP, Alencar MM. Resistência de bovinos de seis graus de sangue holandês-Guzerá ao carrapato B. Microplus e ao berne (Dermatobia hominis). Arq Bras Med Vet Zootec 1990; 42(2): 127-135.

Santos AP, Furlong J. Competição intraespecífica em Boophilus microplus. Ciênc Rural 2002; 32(6): 1033-1038. http://dx.doi.org/10.1590/S010384782002000600018

Srivastava PS, Lata K, Sinha RP. Rabbit a host of Boophilus microplus larvae. Indian J Anim Sci 1986; 10(2): 245.

Srivastava PS, Lata K, Sinha RP. Artificial indution of immunity in rabbits through repeated application of Boophilus microplus larvae. Indian J Anim Sci 1987; 58: 1065-1068.

Tate HD. The biology of the tropical cattle tick and other species of Tick in Puerto Rico, with notes on the efects on ticks of arsenical dips. J Agric Univ P R 1941; 1-24.

Vianna LFCG, Faccini JLH, Pereira MB. Susceptibilidade de Bovinos mestiços ao carrapato Boophilus microplus (Canestrini, 1887) na microregião fluminense do Grande Rio, estado do Rio de Janeiro. Rev Bras Cienc Vet 1995; 2(2): 43-46. 